\title{
Impact of acquisitions on the financial performance of the acquiring companies in Kenya: A case study of listed acquiring firms at the Nairobi securities exchange
}

\author{
George Gitonga Inoti ${ }^{1}$, Samuel Owino Onyuma ${ }^{2}$, Monicah Wanjiru Muiru ${ }^{1}$ \\ ${ }^{1}$ Faculty of Commerce, Department of Accounting, Finance \& Management Science, Egerton University, Nakuru, Kenya \\ ${ }^{2}$ Department of Economics \& Business Studies, Laikipia University, Nyahururu, Kenya
}

\section{Email address:}

gitonganoti@gmail.com (G. G Inoti), sonyuma@yahoo.com (S. Onyuma),mshirom@yahoo.com (M. Muiru)

\section{To cite this article:}

George Gitonga Inoti, Samuel Owino Onyuma, Monicah Wanjiru Muiru. Impact of Acquisitions on the Financial Performance of the Acquiring Companies in Kenya: A Case Study of Listed Acquiring Firms at the Nairobi Securities Exchange. Journal of Finance and Accounting. Vol. 2, No. 5, 2014, pp. 108-115. doi: 10.11648/j.jfa.20140205.12

\begin{abstract}
This study sought to determine whether acquisitions enhance corporate financial performance. The general objective of the study was to assess the effects of acquisitions on the financial performance of the acquiring companies in Kenya. The specific objectives of the study were; to determine the effect of acquisitions on the profitability of the acquiring company and to determine the effect of acquisitions on asset utilization of the acquiring company. Purposive sampling procedure was used to select a sample of all the acquisitions involving listed acquiring companies. Three years pre and post-acquisition financial statements of the acquiring company were examined. Key financial ratios were computed and used to determine the company's pre and post-acquisition financial performance. Paired t-test was used to determine whether there was significant difference between the means of the two periods for each ratio. From the findings it was apparent that there was no significant difference in pre and post-acquisition ratios measuring profitability and asset utilization. The study therefore concluded that corporate acquisitions do not affect the financial performance of the acquiring company.
\end{abstract}

Keywords: Acquisitions, Financial Performance, Nairobi Securities Exchange

\section{Introduction}

Increased competition arising from the fast changing global market has resulted in a situation where firms are finding it increasingly difficult to remain competitive. More than ever before many skills, capacities and resources that are essential to a firm's current and future prosperity are being found outside existing boundaries and outside management's direct control. Accordingly, managers must think outside these boundaries in order to ensure that their firms remain competitive and enter into relationships that will avail tangible and intangible benefits. The changing environments and the new forms of competition have created new opportunities and threats for firms. This has forced many of them to adopt many forms of restructuring activity. It has therefore become common phenomenon for firms to come together in pursuit of a common strategy which avails gains to both firms (Gupta, 2012). Acquisitions are one of the routes that firms are using to achieve required capacities and resources in an effort to increase their earning capacity. According to Piaskoki and Finkelstein (2004), acquisitions bring operational efficiencies which may arise from economies of scale, production economies of scope, consumption economies of scope, improved resource allocation like moving to an alternatively less costly production technology, improved use of information and expertise, a more effective combination of assets and improvements in the use of brand name capital.

Acquisitions create corporate synergies which may result in more efficient management, improved production techniques and exploitation of increased market power. The target company shareholders will be willing to sell their stock to the acquiring company when there are high prospects of higher than normal gains from the sale or when they know their company may not survive alone (Koller at el, 2010). The shareholders of the acquiring company would be willing to pay a price even if high to acquire a target company when they expect that such a purchase would be beneficial to them in the long run. However, various studies done by different 
researchers have failed to agree as to who acquisitions actually benefit. Maditinos et al (2004) suggest that at least in the short run it can never be a win-win situation for the shareholders of the target and acquiring companies. They assert that if the shareholders of the target company gain then this can only be at the expense of the acquiring company shareholders. Recent corporate merger and acquisition activity witnessed in the Kenyan economy is a sign that companies are increasingly accepting this takeover option as a means towards developing their corporate strategies either in the country or in the industry. Besides, the move towards regional integration has indeed sparked a flurry of cross regional expansion which has seen various company's not only use cross-listing across various markets as a means of increasing regional presence but also as a way marked to increase regional acquisitions and buyouts. This has made several Kenyan companies to venture out of the country in cross border acquisitions.

\subsection{Statement of the Problem}

Acquisitions as evidenced by their increased activity seem to be very popular to the corporate players involved. However, they appear to provide at best, a mixed performance to the broad range of stakeholders involved. Numerous studies from around the world have failed to agree on whether acquisitions improve the acquiring firm's financial performance. Some studies show that there is improved post acquisition financial performance for acquiring firms (Azhagaiah and Kumar 2011: Ramaswany and Waegelein, 2003: Kithinji, 2007: Korir, 2006). However, other studies show that acquisitions have no financial benefits for the acquiring firms(Selcuk and Yilmaz, 2011:Yeh and Hoshino: Ndura, 2010). While target firm's shareholders generally enjoy positive short-term returns, investors in bidding firms may experience share price underperformance in the months following acquisition, with negligible or no overall wealth gains for portfolio holders. The Acquiring firm's shareholders may also experience decreased earnings per share as a result of reduced profits. This study therefore seeks to fill the existing research gap by determining the impact of Acquisitions on the financial performance of the acquiring firms in Kenya.

\subsection{Objectives of the Study}

\subsubsection{General Objective}

The general objective of the study is to assess the impact of Acquisitions on the financial performance of the acquiring company in Kenya.

\subsubsection{Specific Objectives}

The specific objectives are;

a) To determine the Pre and post-Acquisition profitability of the acquiring firm

b) To evaluate Pre and Post Acquisition asset utilization of the acquiring firm

\subsection{Research Hypothesis}

$\mathrm{H}_{0}$; There is no significant difference in profitability of the acquiring firm, before and after acquisition.

$\mathrm{H}_{0}$; There is no significant difference in the asset utilization of the acquiring firm before and after acquisition

\section{Literature Review}

\subsection{Acquisitions}

Ross et al. (2007) describes an acquisition as the complete absorption of one firm by another, the acquiring firm retains its name and its identity and it acquires all the assets and liabilities of the acquired firm. Consequently, the acquired firm ceases to exist as a separate business entity. They suggest that business firms find mergers and acquisitions a faster way to enter new markets, eliminate competition and to comply with legislation. According to Hunt (2004), a merger occurs when two relatively equal sized companies come together to form a new company. Therefore, an acquisition occurs when a larger company buys a smaller one. Johnson and Scholes (2002) argue that acquisitions are typically a result of organizations coming together voluntarily or otherwise to actively seek synergistic benefits, perhaps as a result of the common impact of a changing environment in terms of either opportunities or threats or of the excessive costs of innovation.

\subsection{Theories of Acquisitions}

\subsubsection{Differential Efficiency Theory}

Weston et al. (2001) suggest that there are firms with below average efficiency or that are not operating up to their potential. Firms in similar kinds of business activity would most likely be the potential acquirers. They would have the background for detecting below average or less than full potential performance and have the management know-how for the improvement of the performance of the acquired firm. Therefore, this theory suggests that more efficient firms will acquire less efficient firms and realize gains by improving their efficiency.

\subsubsection{Inefficient Management Theory}

Mergers and acquisitions can also be viewed as a response to inefficient management. This scenario is seen where investors in a response to a situation where the incumbent management has pursued inefficient policies and consequently the firm becomes an acquisition target by other firms (Asquith et al, 1983). Sugiarto (2000) observes that inefficient management can be identified from several indicators for example poor earnings undervalued shares and low price earnings ratio. These indicators signify inefficient management and demonstrate that the resources in the target firms are not utilized efficiently which motivates the bidding firm to take over the target firm. 


\subsubsection{Hubris Theory}

In acquisitions, the bidding firm identifies a potential target firm and values its assets. When the valuation turns below the market price (of the stock) then no offer is made. Only when the valuation exceeds the market value, a bid is made. Roll (1986) hypothesizes that managers commit errors of over-optimism in evaluating acquisition opportunities due to excessive pride or hubris. The author argues that a particular bidder may not learn from past mistakes in valuation of target firm and may be convinced that the valuation is correct. Therefore, the takeover phenomenon is as a result of hubris on the part of bidders, the overbearing presumption that their valuation is correct and can never be wrong. Nevertheless, this theory assumes a strong form of market efficiency.

\subsection{Acquisitions Environment in Kenya}

Wesonga (2006) observes that over a long time till the early 1990s the Kenyan economy had been state controlled thus inhibiting mergers and acquisitions activities. However, liberalization and globalization coupled with the opening up of the economy heralded competition in the business environment both from within and outside the country. Since the 1990s there have been increasing number of mergers and acquisitions in Kenyan economy; in 1999 there were 24 acquisitions compared to 23 in 1998 and 11 in 1997 (Cuts, 2002). The report points out that merger and acquisition activity was due to the poor economy where firms had to merge to survive coupled with the awareness of the legal provisions of Cap 504 by the Kenyan business community and statutory requirements especially minimum capital requirements for banks by the Central Bank of Kenya. According to Mwenda (2009), there were a total of 85 acquisitions approved between 2002 and 2006.

The Competition Act (Cap 504) created the Competition authority of Kenya to replace the Monopolies and Prices Commission. The Authority is charged with ensuring fair business practices in the country and to approve and regulate acquisitions. The criteria for determining whether mergers and acquisitions are prejudicial to public interest are set out in sections 30 of the Act. Section 27 of the Act states that businesses may combine through acquisitions whereby the assets of two or more companies become vested in or under control of one company. Additionally, mergers and acquisitions in Kenya are regulated by the Capital Markets Authority Act. The regulations under this Act prescribe the procedure to be followed in the transactions as well as setting the time lines within which they must be done.

\subsection{Empirical Evidence on the Effect of Acquisitions on Financial Performance}

Selcuk and Yilmaz (2011) conducted a study on the impact of acquisitions on acquirer performance in Turkey using the stock market approach and the accounting method. Under the stock market approach, they concluded that stock returns for Turkish companies during the event window period were higher than the industry average. Under the accounting approach they used three profitability ratios; Return on Assets (ROA), Return on Equity (ROE) and Return on Sales (ROS) to measure performance. According to their results, post-acquisition ROA and ROS were significantly lower than the pre acquisition's. However, the results revealed that ROE does not decline significantly as a result of acquisitions. They concluded that on overall using the accounting approach, acquisitions negatively affect financial performance of the acquiring companies.

A review by Pilloff and Santomero (1997) of various studies studies on the value effects of bank acquisitions in the studies revealed that on the average there was no statistically significant gain in value or performance from acquisition activity. Their study indicated that the acquired firm shareholders gain at the expense of the acquiring firm. They assert that this is documented over the course of many studies covering different time periods and different locations. Furthermore, Yeh and Hoshino (2002) examined the effects of acquisitions on the firm's operating performance using a sample of 86 Japanese corporate acquisitions between 1970 and 1994. The successfulness of acquisitions was tested based on efficiency, profitability and growth. The study used total productivity as an indicator of the firm's efficiency or productivity, ROA and ROE as indicators of the firm's profitability and sales and growth in employment to indicate the firm's growth. The results of their study indicated a significant downward trend on profitability and sales growth. Additionally, their study results showed an insignificant downward trend in productivity. According to their conclusions, acquisitions have a negative impact on firm performance in Japan.

Azhagaiah and Kumar (2011) did a study on the short-term post-acquisition performance of corporate firms in India. They used a sample of 20 acquiring firms listed on the Bombay Stock Exchange for one year. According to their conclusions, acquiring firms in India tend to perform better after an acquisition in the short run as compared to the pre-acquisition period. They attributed this to enhanced efficiency in utilization of their assets which lead to generation of higher operating cash flows. Likewise, Ramaswamy and Waegelein (2003) studied the long-term post-acquisition performance of companies involved in mergers and acquisitions activity in Hong Kong. The study comprised of 162 firms for a period of 15 years $(1975-1990)$ and the analysis covered a five years pre and post-acquisition period. According to their conclusions, there is a significant positive improvement of the post-acquisition performance as compared to the pre-acquisition. However, they observed that the post-acquisition performance was significantly tied to the relative sizes of the firms coming together; firms acquiring relatively bigger firms took longer times to digest them. They also found out that conglomerate acquisitions tended to bring in better post-acquisition results than acquisitions of firms in the same industry.

Kithinji (2007) carried out a study on the effects of acquisitions on financial performance of non- listed banks in 
Kenya. He used a sample derived from the period between 1994 and 2001.Comparative analysis of the bank's performance for 5 years pre and post-merger and acquisition was carried out using profitability, return on assets, shareholder equity and total assets ratios. The findings of the study indicated that there was a significant improvement in the performance of non-listed banks which merged as compared with the non-listed ones that didn't merge. Similarly, Korir (2006) examined the effects of mergers and acquisitions on the performance of companies listed at the NSE. A sample of 10 listed companies that were involved in mergers and acquisitions during the period and another of 10 listed companies that were not involved in mergers and acquisitions over the same period were used. He used share turnover, volume of shares traded, market capitalization and profits to measure financial performance. The results of the study indicated that there was a positive improvement in the performance of the companies involved in acquisitions.

\section{Research Methodology}

\subsection{Research Design and Target Population}

The study adopted a descriptive research design. The target population of the study comprised all the 128 Mergers and Acquisitions in Kenya between 2001 and 2010.

\subsection{Sampling Design and Sample Size}

The study adopted purposive sampling technique, where 11 acquisitions involving listed acquiring companies were examined. The 11 firms included in the sample were the ones that had specific characteristics that were required for this study; must have been listed at the NSE and must have been the acquiring firm.

\subsection{Data Collection and Analysis}

The study used secondary data which was collected 3 years pre and 3 years post acquisition from the financial statements of the company's. Net profit margin ratio, earnings per share and return on capital employed ratios were used to calculate pre and post-acquisition profitability. On the other hand, the study used total asset turnover ratio, fixed assets turnover ratio and working capital turnover ratio in order to calculate pre and post-acquisition asset utilization. Mean was then calculated for each recorded ratio to obtain pre-acquisition and post-acquisition means. A two tailed t-test was performed on the calculated means do determine whether there was any significant difference between the pre and post-acquisition financial performance.

\section{Results and Discussion}

\subsection{Impact of Acquisitions on Profitability}

Table 1. Net Profit Margin Changes.

\begin{tabular}{|c|c|c|c|c|}
\hline Company & NP Margin Before & NP Margin After & Difference & $\%$ Change \\
\hline Crown-berger & 0.04 & 0.03 & $(0.01)$ & (17.37) \\
\hline $\mathrm{KCB}$ & 0.21 & 0.26 & 0.05 & 25.32 \\
\hline Total Kenya & 0.01 & 0.01 & $(0.00)$ & $(39.41)$ \\
\hline Access Kenya & 0.12 & 0.05 & $(0.07)$ & $(60.97)$ \\
\hline CFC Bank & 0.19 & 0.12 & $(0.07)$ & $(36.25)$ \\
\hline Scan group & 0.06 & 0.06 & 0.01 & 10.32 \\
\hline Standard Ltd & 0.09 & 0.08 & $(0.02)$ & $(17.82)$ \\
\hline Kenya Oil & 0.02 & 0.01 & $(0.00)$ & $(22.67)$ \\
\hline Pan Africa Insurance & $(1.74)$ & 0.20 & 1.94 & 111.60 \\
\hline East Africa Breweries & 0.10 & 0.14 & 0.04 & $43.39 \mathrm{~S}$ \\
\hline
\end{tabular}

The results in Table 1 show that the 11 Companies had a pre -acquisition net profit mean of -0.08 which improved to 0.1 after acquisition. Paired t-test was used to test whether the difference between the pre and post-acquisition mean ratios were statistically different. The calculated statistical $t$ value was 0.97 which was below the critical t value of 2.228. This means there was no significant difference in the net profit ratios 3 years before and after acquisition. Thus, this study fails to reject the null hypothesis and concludes that there is no difference in profitability before and after acquisition.

\subsubsection{EPS as a Measure of Profitability}

According to the results in Table 2 below, all the companies had a positive EPS apart from the Pan Africa Insurance company

That posted losses during the 3years before acquisition. The pre-acquisition mean EPS for the eleven companies was 3.54 which improved to 4.36 after acquisitions. The calculated 2 tailed test value was 2.2281 which was higher than the calculated t value of 1.021. Consequently, this study fails to reject the null hypothesis and concludes that acquisitions do not have any significant impact on the profitability of the acquiring company based on the EPS. 
Table 2. Earnings per Changes.

\begin{tabular}{lllll}
\hline Company & EPS before Acquisition & EPS after Acquisition & Difference & \% Change \\
\hline Crown-berger & 2.13 & 2.10 & $(0.03)$ & $(1.56)$ \\
KCB & 1.73 & 3.74 & 2.02 & 116.79 \\
Total Kenya & 3.26 & 1.48 & $(1.78)$ & $(55.43)$ \\
Access Kenya & 0.86 & 0.38 & $(0.48)$ & $(55.43)$ \\
CFC Bank & 2.30 & 4.38 & 2.08 & 90.30 \\
TPS Eastern Africa & 1.25 & 3.21 & 1.96 & 157.15 \\
Scan group & 1.50 & 2.26 & 0.76 & 50.67 \\
Standard Ltd & 2.83 & 3.20 & 0.31 & 10.73 \\
Kenya Oil & 7.71 & 3.49 & $(4.23)$ & $(54.80)$ \\
Pan Africa Insurance & $(1.33)$ & 5.00 & 6.33 & 475.96 \\
East Africa Breweries & 16.64 & 18.74 & 2.10 & 12.60 \\
Mean & 3.54 & 4.36 & & \\
\hline
\end{tabular}

\subsubsection{Return on Capital Employment as a Profitability Measure}

Table 3. ROCE before and after Acquisition

\begin{tabular}{lllll}
\hline Company & ROCE before acquisition & ROCE after acquisition & Difference & \% Change \\
\hline Crown-berger & 0.14 & 0.13 & -0.01 & -4.39 \\
KCB & 0.04 & 0.23 & 0.19 & 483.33 \\
Total Kenya & 0.25 & 0.14 & -0.11 & -43.58 \\
Access Kenya & 0.19 & 0.14 & -0.05 & -24.90 \\
CFC Bank & 0.06 & 0.16 & 0.10 & 179.82 \\
TPS Eastern Africa & 0.07 & 0.11 & 0.04 & 60.22 \\
Scan group & 0.25 & 0.04 & -0.21 & -84.90 \\
Standard Ltd & 0.38 & 0.29 & -0.09 & -23.67 \\
Kenya Oil & 0.17 & 0.16 & -0.01 & -3.86 \\
Pan Africa Insurance & -0.03 & 0.08 & 0.11 & -338.79 \\
East Africa Breweries & 0.38 & 0.52 & 0.15 & 38.50 \\
Mean & 0.17 & 0.18 & & \\
\hline
\end{tabular}

\subsubsection{Return on Equity}

According to the results in table 4 below, seven companies recorded a drop in their Return on Equity after acquisition. The Standard Ltd recorded the highest drop, from 0.34 to 0.17. The mean pre-acquisition ROE for the sampled companies was 0.14 which surprisingly did not change after acquisitions. This generally shows that the mean return on capital never improved after acquisitions. The Paired t-test was done at $5 \%$ level of significance at $10 \mathrm{df}$ for which the critical $t$ was 2.2281 and the calculated $t$ was found to be -.023 . Thus, this study fails to reject the null hypothesis as there is no significant difference between the mean ROE before and after acquisition.

Table 4. Return on Equity before and after Acquisition.

\begin{tabular}{|c|c|c|c|c|}
\hline Company & ROE before acquisition & ROE after acquisition & Difference & \% Change \\
\hline Crown-berger & 0.08 & 0.07 & -0.01 & -9.12 \\
\hline $\mathrm{KCB}$ & 0.20 & 0.15 & -0.05 & -26.46 \\
\hline Total Kenya & 0.12 & 0.05 & -0.07 & -60.09 \\
\hline Access Kenya & 0.16 & 0.07 & -0.09 & -55.58 \\
\hline CFC Bank & 0.03 & 0.14 & 0.11 & 443.04 \\
\hline TPS Eastern Africa & 0.05 & 0.09 & 0.04 & 74.65 \\
\hline Standard Ltd & 0.34 & 0.17 & -0.17 & -49.92 \\
\hline Kenya Oil & 0.17 & 0.12 & -0.06 & -31.59 \\
\hline Pan Africa Insurance & -0.08 & 0.22 & 0.30 & 370.46 \\
\hline East Africa Breweries & 0.25 & 0.30 & 0.05 & 18.98 \\
\hline Mean & 0.14 & 0.14 & & \\
\hline
\end{tabular}

\subsection{Impact of Acquisitions on Asset Utilization}

\subsubsection{Total Assets Turnover Ratio as a Measure of Assets Utilization}


Table 5. Total Asset Turnover before and after acquisition.

\begin{tabular}{lllll}
\hline Company & T.A Turnover Ratio before acquisition & T.A Turnover Ratio after acquisition & Difference & \% Change \\
\hline Crown-berger & 1.17 & 1.92 & 0.74 & 63.29 \\
KCB & 0.72 & 0.62 & $(0.10)$ & $(13.54)$ \\
Total Kenya & 9.45 & 5.88 & $(3.58)$ & $(37.83)$ \\
Access Kenya & 1.16 & 1.17 & 0.01 & 0.86 \\
CFC Bank & 0.52 & 0.78 & 0.27 & 52.11 \\
TPS Eastern Africa & 0.99 & 0.67 & $(0.33)$ & $(32.75)$ \\
Scan group & 4.37 & 2.48 & $(1.89)$ & $(43.20)$ \\
Standard Ltd & 2.42 & 1.34 & $(1.08)$ & $(44.65)$ \\
Kenya Oil & 7.79 & 9.17 & 1.38 & 17.67 \\
Pan Africa Insurance & 0.14 & 0.45 & 0.31 & 220.46 \\
East Africa Breweries & 2.65 & 2.24 & $(0.41)$ & $(15.31)$ \\
Mean & 2.85 & 2.37 & & \\
\hline
\end{tabular}

According to the results in table 5, the mean total assets turnover ratio was 2.85 before acquisitions and this went down to 2.37 after acquisition. Furthermore, a two-tailed paired $t$ test was performed at 5\% levels of confidence and $10 \mathrm{df}$ with the $\mathrm{t}$ critical value being 2.228 . The calculated $t$ value was found to be -1.035 , which was not in the region of the critical $\mathrm{t}$ value. Therefore, based on the total assets turnover ratio this study fails to reject the null hypothesis and concludes that there is no statistical significant difference between the total asset turnover means of the companies before and after acquisitions.

\subsubsection{Fixed Assets Turnover Ratio as a Measure of Asset Utilization}

The results in table 6 indicate that there was a decline in the mean fixed asset turnover ratio from 11.35 before acquisitions to 10.93 after acquisition. A two tailed paired t-test was performed at 5\% level of significance and 10df and revealed a calculated $t$ of -0.1305 which was lower than the critical $t$ of 2.2281.As a result, this study concludes that there is no significant difference between the pre and post-acquisition fixed asset turnover means.

Table 6. Fixed Asset Turnover Ratio before and after Acquisition.

\begin{tabular}{|c|c|c|c|c|}
\hline Company & F.A Turnover Ratio before acquisition & F.A Turnover Ratio after acquisition & Difference & $\%$ Change \\
\hline Crown-berger & 2.74 & 3.88 & 1.14 & 41.53 \\
\hline $\mathrm{KCB}$ & 2.97 & 4.71 & 1.73 & 58.24 \\
\hline Total Kenya & 13.44 & 11.10 & $(2.34)$ & $(17.38)$ \\
\hline Access Kenya & 3.98 & 1.25 & $(2.74)$ & $(68.67)$ \\
\hline CFC Bank & 4.31 & 5.38 & 1.07 & 24.87 \\
\hline TPS Eastern Africa & 1.16 & 0.09 & $(1.07)$ & $(92.14)$ \\
\hline Scan group & 66.00 & 40.04 & $(25.96)$ & $(39.33)$ \\
\hline Kenya Oil & 20.92 & 23.77 & 2.85 & 13.60 \\
\hline Pan Africa Insurance & 2.71 & 24.04 & 21.33 & 787.83 \\
\hline East Africa Breweries & 3.30 & 4.32 & 1.02 & 31.03 \\
\hline Mean & 11.35 & 10.93 & & \\
\hline
\end{tabular}

\subsubsection{Working Capital Turnover Ratio}

The mean working capital turnover ratio for the eleven companies before acquisition was 9.25 and after acquisition it dropped to 8.05. This indicates that there was a drop in the utilization of working capital after acquisition. The calculated $\mathrm{t}$-value was found to be -0.4009 against the critical $\mathrm{t}$ which was 2.2281. Thus, this study concludes that there is no statistical significant difference between the utilization of assets before and after acquisition.

Table 7. Working Capital Turnover Ratio.

\begin{tabular}{lllll}
\hline Company & W.C Turnover Ratio before acquisition & W.C Turnover Ratio after acquisition & Difference & \% Change \\
\hline Crown-berger & 3.91 & 4.25 & 0.34 & 8.62 \\
KCB & -1.60 & -0.01 & 1.58 & -99.15 \\
Total Kenya & 22.31 & 32.42 & 10.11 & 45.32 \\
Access Kenya & 15.30 & -7.56 & -22.85 & -149.39 \\
CFC Bank & -3.68 & -1.28 & 2.40 & -65.28 \\
TPS Eastern Africa & 23.66 & 28.57 & 4.91 & 20.75 \\
Scan group & 5.63 & 3.31 & -2.32 & -41.25 \\
Standard Ltd & 11.95 & 18.46 & 6.51 & 54.46 \\
Kenya Oil & 21.69 & 19.54 & -2.15 & -9.89 \\
Pan Africa Insurance & 1.54 & -14.99 & -16.53 & -1073.92 \\
East Africa Breweries & 1.06 & 5.84 & 4.77 & 448.39 \\
Mean & 9.25 & 8.05 & & \\
\hline
\end{tabular}


The three efficiency ratios indicate that there was no difference in assets utilization by the acquiring companies before and after they made acquisitions. However, there were noted increases in asset utilization in some companies as revealed by the ratios. This may have been because of increased marginal revenues after acquisitions as compared to the marginal increase in assets. Conversely, other companies showed decreased ability to utilize their assets in revenue generation. This could have been because their assets after acquisition may have increased at a greater rate as compared to the increase in revenues.

\section{Summary and Conclusions}

The main objective of the study was to determine the impact of Acquisitions on the financial performance of the acquiring company in Kenya. In regard to profitability, 3 of the 4 ratios used indicated that mean post acquisition ratios decreased as compared to pre-acquisition means; the NP ratio, EPS, ROCE decreased from 0.097 to $-0.076,4.4$ to 3.5 and 0.18 to 0.17 respectively. The mean ROE ratio after acquisition remained the same as before; at 0.14 . Nonetheless, Paired t-test results showed that there was no statistical significant difference between the pre post acquisition means. From the results obtained, the study failed to reject the null hypotheses thus concluding that there was no significant difference between the profitability of a NSE listed acquiring company before and after acquisition. In relation to the asset utilization of the acquiring companies, three different ratios were employed, the Total Assets Turnover, Fixed Assets Turnover and the Working Capital Turnover. The pre-acquisition means were $2.4,10$ and 8.0 while the post-acquisition means were $2.9,11.3$ and 9.2 respectively. This clearly shows that there was a marginal increase in asset utilization after acquisition. However, the calculated t-test values for the three ratios were outside the region of the $t$ critical, therefore it was concluded that there was no significant difference between the pre and post-acquisition asset utilization levels for the acquiring company. Therefore, the study concluded that acquisitions have no impact on the NSE listed acquiring company's financial performance.

This study is consistent with the findings of Pilloff and Santomero (1997) who did a review of several studies done on the value effects of Mergers and Acquisitions in the USA and concluded that on average, there was no statistically significant gain in Value or better performance after the M\&A. This study is also consistent with the findings of Ndura (2010) who established that mergers and acquisitions had no effect on profitability, capital adequacy and long term solvency of the acquiring firm. It also agrees with Chesang (2002) who found that mergers and acquisitions did not affect the post-acquisition financial performance of Kenyan Commercial Banks. The findings of this study however dispute that of Korir (2006) who concluded that there was significant improvement in financial performance after mergers and acquisitions. Nonetheless, his study included merging companies unlike the current study which purely focused on acquisitions. This may explain the difference between the findings of the two studies.

\section{Recommendations for Further Study}

It is recommended that further studies be done on the impact of acquisitions on the financial performance of the acquiring company using the stock price method for companies listed at the NSE. This is because the current study used the accounting method where financial ratios were used to analyze the financial statements. Such a study, if done would help to confirm or dispute the findings of this study. Also studies on the impact of acquisitions on the acquiring company's shareholders wealth in Kenya should be done. This would help to find out whether acquisitions ultimately benefit the shareholders of the acquiring company in Kenya or whether it could be value reducing as asserted by Pilloff and Santomero (1997).

\section{References}

[1] Asquith, P., Bruner R., \& Mullins, D. (1983). The Gains to bidding firms from Acquisitions. Journal of Financial Economics, 11, 121-140.

[2] Azhagaiah, R., \& Kumar T. (2011). Mergers \& Acquisitions: An empirical study on the Short- term Post-Acquisition Performance of Corporate Firms in India. International Journal of Research in Commerce, Economics \& Management, 1, 80-104.

[3] Chesang, C. (2002). Acquisition Restructuring and Financial Performance of Commercial Banks in Kenya. Unpublished MBA Thesis. University of Nairobi.

[4] Cuts. (2002). Promoting Competitiveness \& Efficiency in Kenya. The role of Competition Policy \& Law.Nairobi, Institution of Economic Affairs of Kenya.

[5] Gupta, K.,(2012). Mergers and Acquisitions: The Strategic Concepts for the Nuptials of Corporate Sector. Innovative Journal of Business and Management. 1, 60-68.

[6] Hunt, P. (2004). Structuring Mergers and Acquisitions: A guide to creating shareholder value. ( $\left.2^{\text {nd }} \mathrm{ed}\right)$. New York: Aspen Publishers.

[7] Johnson, G. \& Scholes, K. (2002). Exploring Corporate Strategy. New York: Prentice hall.

[8] Kithinji, M. (2007). Effects of Acquisitions on Financial Performance of Non Listed Banks in Kenya. Unpublished MBA Thesis. University of Nairobi.

[9] Koller, T., Goedhart, M., \& Wessels, D.(2010). Valuation: Measuring and Managing the Value of Companies. Hoboken, John Wiley \& Sons.

[10] Korir, E. (2006). Effects of Acquisitions on Financial Performance of Companies listed at the NSE. Unpublished MBA Thesis. University of Nairobi.

[11] Maditinos, D., Theriou, N. \& Demtriades, E. (2008). The Effect of Mergers \& Acquisitions on Performance of Companies- the Greek case of Ioniki - Laiki Bank and pisteos Bank. Journal of European research Studies, 11, 111-130. 
[12] Mwenda, J. (2009). A empirical evaluation of pre and post acquisitions success factors and the impact of culture on acquisitions and acquisitions in Kenya. Unpublished MBA thesis. University of Nairobi.

[13] Ndura, K. (2010). Effects of Acquisitions on Financial Performance of Insurance Companies in Kenya. Unpublished MBA Thesis. University of Nairobi.

[14] Piaskoski, M., \& Finkelstein, N. (2004). Do Merger Efficiencies Receive Superior Treatment in Canada? Some legal, Policy and Practical Observations Arising from the Canadian Superior Propane Case. World Competition, 2, 259-298.

[15] Pilloff, S., \& Santomero, A. (1997). The Value Effect of Bank Mergers and Acquisitions, Working Paper, No. 97 (7), The Wharton Financial Institutions Centre.

[16] Ramaswamy, K., \& Waegelein, J. (2003). Firm Financial performance following acquisitions. Review of Quantitative Finance and Accounting, 20, 13-23

[17] Roll, R. (1986). The Hubris Hypothesis of Corporate Control. Journal of Business, 59, 197 - 216.
[18] Ross, S., Westerfied, R., \& Jaffe, J. (2004). Corporate Finance. New Delhi: Tata Mcgraw-Hill. Ross, S.,Westerfield, R., Jaffe, J., \& Jordan, B.(2007). Corporate Finance. Core Principles and Applications. $\left(2^{\text {nd }}\right.$ ed). New York: McGrawHill/Irwin.

[19] Selcuk, A., \& Yilmaz, A. (2011). The Impact of Acquisitions on acquirer performance: Evidence from Turkey. Business and Economics Journal, 22,1-7.

[20] Surgiarto, A. (2000).The Effect of Mergers \& Acquisitions on Shareholder Returns. Unpublished Phd Thesis. Victoria University of Technology.

[21] Wesonga, M. (2006). A survey of Factors that Determine the Choice of Mergers and Acquisitions Partners in Kenya. Unpublished MBA Thesis. University of Nairobi.

[22] Weston, J., \& Weaver, S.(2001). Mergers and Acquisitions. New York: McGraw-Hill.

[23] Yeh, T., \& Hoshino, Y. (2002). Productivity and Operating Performance of Japanese Merging Firms: Keiretsu- related and Independent Acquisitions. Japanese and the World Economy, 14, 243-366. 